\title{
ANALISIS BIAYA SATUAN PENDIDIKAN DI SMK NEGERI 1 JOGONALAN TAHUN AJARAN 2014/2015
}

\section{ANALYSIS OF EDUCATION UNIT COST IN SMK NEGERI 1 JOGONALAN ACADEMIC YEAR 2014/2015}

\author{
Oleh: \\ Adelina Vina Hapsari \\ Pendidikan Akuntansi Universitas Negeri Yogyakarta \\ adelinavina@gmail.com
}

$\underline{\text { Sukirno }}$

Staf Pengajar Jurusan Pendidikan Akuntansi Universitas Negeri Yogyakarta

\begin{abstract}
Abstrak
Penelitian ini bertujuan untuk mengetahui besarnya Biaya Satuan Pendidikan di SMK Negeri 1 Jogonalan Tahun Ajaran 2014/2015 yang terdiri dari Biaya Operasi dan Biaya Investasi Selain Lahan Pendidikan. Teknik pengumpulan data menggunakan dokumentasi dan observasi dengan instrumen penelitian berupa cheklist. Teknik analisis data yang digunakan adalah deskriptif dengan pendekatan kuantitatif dan kualitatif. Hasil penelitian menunjukkan bahwa (1) Biaya Operasi per peserta didik sebesar Rp5.416.538,78; (2) Biaya Investasi Selain Lahan Pendidikan per peserta didik sebesar Rp999.963,51; (3) Biaya Satuan Pendidikan per peserta didik sebesar Rp6.416.502,29; (4) Sumber dana berasal dari APBN sebesar Rp1.326.100.444,00; APBD 1 Rp8.000.000,00; APBD 2 sebesar Rp2.474.333.996,00; SOT sebesar Rp1.806.538.069,00; dan Sumber lain sebesar Rp12.300.000,00. (5) Biaya Operasi Nonpersonalia di SMK Negeri 1 Jogonalan belum sesuai dengan Standar Biaya Operasi Nonpersonalia di Kabupaten Klaten. Jumlah Biaya Operasi Nonpersonalia di Kabupaten Klaten sebesar Rp1.323.786.240,00 sedangkan di SMK Negeri 1 Jogonalan sebesar Rp1.214.231.444,00.
\end{abstract}

Kata Kunci: Biaya Operasi, Biaya Investasi Selain Lahan Pendidikan, Biaya Satuan Pendidikan

\begin{abstract}
This research is aimed at analyzing the amount of Education Unit Costs in SMK Negeri 1 Jogonalan Academic Year 2014/2015 that consist of Operational Cost and Non Educational Field Investment Cost. The Writer used documentation and observation with checklist as the instrument of the study to collect the data. The writer also used descriptive qualitative and quantitative approach to analyze data. The results show that (1) Operational Costs for each student is Rp5.416.538,78; (2) Non Educational Field Investment Cost for each student is Rp999.963,51; (3) Education Unit Cost for each student is Rp6.416.502,29; (4) The source of funds from State Budget is Rp1.326.100.444,00; Regional Budget 1 is Rp8.000.000,00; Regional Budget 2 is Rp2.474.333.996,00; Contribution of Parents is Rp1.806.538.069,00; and other source is Rp12.300.000,00; (5) Nonpersonnel Operational Cost in SMK Negeri 1 Jogonalan has not fitted Nonpersonnel Operational Cost in Klaten region. The amount of Nonpersonnel Operational Costs in Klaten region is Rp1.323.786.240,00 while in SMK Negeri 1 Jogonalan is Rp1.214.231.444,00.
\end{abstract}

Keywords: Operational Cost, Non Educational Field Investment Cost, Education Unit Cost 


\section{PENDAHULUAN}

Peraturan Pemerintah Nomor 19 Tahun 2005 tentang Standar Nasional Pendidikan dan Nomor 65 Tahun 2005 tentang Standar Pelayanan Minimal menuntut sekolah untuk meningkatkan mutu pendidikan. Hal ini berimplikasi pada kenaikan biaya pendidikan. Biaya pendidikan adalah semua pengeluaran yang memiliki kaitan langsung dengan penyelenggaraan pendidikan (Harsono, 2007:9). Banyaknya komponen yang harus dibiayai dalam penyelenggaraan pendidikan tidak cukup hanya dengan mengandalkan dana dari satu sumber seperti dari pemerintah pusat saja, atau dari pemerintah daerah saja, tetapi harus diakomodasi dari pemerintah pusat dan pemerintah daerah. Keterbatasan pemerintah pusat dan pemerintah daerah untuk membiayai penyelenggaraan pendidikan maka perlu adanya partisipasi dari masyatakat untuk mendukung pembiayaan pendidikan.

Peraturan Pemerintah No 48 Tahun 2008 tentang Pendanaan Pendidikan pasal 2 ayat (1) menyatakan bahwa "Pendanaan pendidikan menjadi tanggung jawab bersama antara Pemerintah, Pemerintah Daerah, dan masyarakat". Menurut Peraturan Pemerintah Nomor 19 Tahun 2005 tentang Standar Nasional Pendidikan Pasal 62 biaya pendidikan terdiri atas

Biaya Investasi, Biaya Operasi dan Biaya Personal.

Berdasarkan hasil wawancara dengan Bapak Sridadi, S.Pd., M.Pd, Wakil Kepala Sekolah Manajemen Mutu SMK Negeri 1 Jogonalan sumber pendanaan di SMK Negeri 1 Jogonalan berasal dari APBN, APBD 1 (Provinsi Jawa Tengah), APBD 2 (Kabupaten Klaten), Sumbangan Orang Tua (SOT), dan sumber lain
(GNOTA dan Supersemar). SMK Negeri 1 Jogonalan mendapatkan bantuan pendanaan berupa Bantuan Operasional Sekolah (BOS) sejak tahun ajaran 2012/2013. Akan tetapi bantuan yang diperoleh dari pemerintah belum cukup untuk mendanai seluruh penyelenggaraan pendidikan karena sebagai sekolah menengah kejuruan membutuhkan dana yang lebih banyak dari pada sekolah menengah umum terutama untuk melakukan kegiatan praktek peserta didik. Untuk menutupi kekurangan dana maka sekolah mengadakan sumbangan dari orang tua berupa Sumbangan Pembinaan Pendidikan (SPP).

Tarif SPP di SMK Negeri 1 Jogonalan setiap tahunnya mengalami perubahan. Pada tahun ajaran 2012/2013 sebesar Rp123.000,00; tahun ajaran 2013/2014 sebesar Rp 78.000,00; dan tahun ajaran 2014/2015 sebesar Rp 93.000,00. Penurunan tarif SPP pada tahun ajaran 2013/2014 dikarenakan dana BOS yang diterima lebih besar dibandingkan dengan pada tahun ajaran 2012/2013. Kenaikan tarif SPP pada tahun ajaran 2014/2015 dikarenakan komponen yang dibiayai lebih banyak seperti penambahan ruangan dan peralatan praktik untuk program keahlian Teknik Komputer dan Jaringan (TKJ) yang merupakan program keahlian baru serta dampak dari kenaikan harga kebutuhan di pasaran. Sumber bantuan pendanaan yang diterima sekolah juga tetap sehingga biaya yang harus ditanggung oleh orang tua peserta didik menjadi lebih besar. Hal ini membuat orang tua sebagai pihak yang menanggung biaya mengeluh dan menanyakan penggunaan uang yang telah dibayarkan.

Sebagai sekolah berstatus negeri, maka SMK Negeri 1 Jogonalan harus 
menerapkan tata kelola yang baik (good governance) pada setiap aktivitasnya. Ada dua pilar good governance yaitu akuntabilitas dan transparansi yang menjadi dasar dalam membuat dan menyajikan laporan pengelolaan keuangan sekolah yang memuat informasi biaya baik kepada pemerintah dan masyarakat. Penyajian informasi biaya bisa dilakukan apabila manajemen dapat mengidentifikasi biayabiaya yang digunakan untuk melakukan kegiatan. Oleh karena itu, sekolah membuat kebijakan tentang biaya-biaya yang dituangkan dalam dokumen Rencana Kerja dan Anggaran Sekolah (RKAS). RKAS memuat informasi biaya-biaya yang akan dikeluarkan sekolah beserta sumber-sumber yang mendanai biaya pendidikan tersebut. RKAS juga sebagai dasar dalam menghitung Biaya Satuan Pendidikan. Nanang Fattah (2002: 24) menyatakan bahwa biaya satuan ditingkat sekolah merupakan agregat biaya pendidikan tingkat sekolah, baik yang bersumber dari pemerintah, orang tua, dan masyarakat yang dikeluarkan untuk penyelenggaraan pendidikan dalam satu tahun pelajaran. Biaya satuan per peserta didik merupakan ukuran yang menggambarkan seberapa besar biaya yang dialokasikan ke satuan pendidikan secara efektif untuk kepentingan peserta didik dalam menempuh pendidikan.

Di SMK Negeri 1 Jogonalan belum ada analisis mengenai Biaya Satuan Pendidikan. Penghitungan Biaya Satuan Pendidikan diperlukan sekolah dalam menetapkan biaya penyelenggaraan pendidikan yang harus ditanggung oleh masing-masing peserta didik. Biaya Satuan Pendidikan per peserta didik menggambarkan secara rinci atas beban peserta didik selama mengikuti pendidikan di sekolah. Beban unit setiap peserta didik akan ditandingkan dengan subsidi pemerintah pusat, pemerintah daerah, dan masyarakat sehingga dapat diketahui jumlah beban yang harus ditanggung oleh peserta didik. Biaya Satuan Pendidikan per peserta didik akan menjadi landasan akuntabilitas keuangan sekolah kepada publik dan menjadi dasar dalam pengambilan keputusan. Dengan penghitungan yang detail dan transparan akan memberikan informasi biaya yang harus dikeluarkan oleh sekolah untuk dapat memberikan pelayanan pendidikan dan besarnya dana tambahan dari masyarakat untuk menutup biaya jika pendapatan sekolah dari pemerintah dan bantuan-bantuan lainnya belum mencukupi sehingga mudah mendorong partisipasi masyarakat dalam hal pendanaan untuk sekolah.

Berdasarkan uraian tersebut, penelitian ini bertujuan menentukan besarnya Biaya Operasi dan Biaya Investasi Selain Lahan Pendidikan di SMK Negeri 1 Jogonalan Tahun Ajaran 2014/2015.

\section{METODE PENELITIAN}

Tempat penelitian dilakukan di SMK Negeri 1 Jogonalan yang beralamat di Tegalmas, Prawatan, Jogonalan, Klaten. Waktu penelitian di mulai pada bulan Desember 2014 sampai bulan Februari 2015.

Subjek penelitian ini adalah Ketua Tim RKAS, Bendahara, dan Pegawai Tata Usaha. Objek penelitian ini adalah Biaya Satuan Pendidikan yang meliputi Biaya Operasi dan Biaya Investasi Selain Lahan Pendidikan.

Instrumen penelitian yang digunakan dengan menggunakan cheklist (daftar cocok). Komponen yang akan diamati 
meliputi sarana dan prasarana yang ada di SMK Negeri 1 Jogonalan.

Teknik analisis data menggunakan deskriptif secara kuantitatif dan kualitatif dengan bantuan program microsoft excel untuk menggambarkan dan memprediksi pembiayaan di sekolah. Langkahlangkahnya yaitu dengan melakukan penghitungan Biaya Satuan Pendidikan dengan (a) mengumpulkan dokumen RKAS, rekapitulasi gaji dan tunjangan PNS, rekapitulasi jumlah peserta didik tahun ajaran 2014/2015, data guru dan karyawan SMK Negeri 1 Jogonalan, dan profil sekolah; (b) mengklasifikasikan komponen yang termasuk kelompok Biaya Operasi Personalia, Biaya Operasi Nonpersonalia, dan Bantuan Beasiswa; (c) mengklasifikasikan komponen yang termasuk kelompok Biaya Investasi Selain Lahan Pendidikan; (d) Menghitung Biaya Operasi per peserta didik dengan membagi total Biaya Operasi dengan jumlah peserta didik; (e) menghitung Biaya Investasi Selain Lahan Pendidikan per peserta didik dengan membagi total Biaya Investasi Selain Lahan Pendidikan dengan jumlah peserta didik, (f) menghitung Biaya Satuan Pendidikan per peserta didik dengan membagi total Biaya Satuan Pendidikan (total Biaya Operasi dan total Biaya Investasi Selain Lahan Pendidikan) dengan jumlah seluruh peserta didik, (g) menentukan sumber-sumber yang mendanai Biaya Satuan Pendidikan.

Langkah selanjutnya yaitu menganalisis hasil perhitungan dengan cara membandingkan jumlah Biaya Operasi Nonpersonalia di SMK Negeri 1 Jogonalan dengan standar Biaya Operasi Nonpersonalia Kabupaten Klaten.

\section{HASIL PENELITIAN DAN PEMBA- HASAN}

Biaya pendidikan di SMK Negeri 1 Jogonalan meliputi Biaya Operasi dan Biaya Investasi Selain Lahan Pendidikan. Biaya Operasi terdiri dari Biaya Operasi Personalia, Biaya Operasi Nonpersonalia, dan Bantuan Beasiswa. Total Biaya Operasi Personalia di SMK Negeri 1 Jogonalan Tahun Ajaran 2014/2015 yaitu sebesar Rp 3.248.773.065,00 yang meliputi gaji dan tunjangan PNS sebesar Rp 2.442.379.000,00; tambahan penghasilan sebesar Rp 9.360.000,00; gaji guru honorer sebesar Rp 181.675.000,00; gaji pegawai honorer sebesar Rp 129.675.065,00; honor selain gaji dan tunjangan sebesar $\mathrm{Rp}$ 406.824.000,00; kesejahteraan tambahan (maslahat) sebesar Rp 49.360.000,00; dan Pengembangan SDM sebesar Rp 29.500.000,00.

Total Biaya Operasi Nonpersonalia di SMK Negeri 1 Jogonalan Tahun Ajaran 2014/2015 sebesar Rp1.214.231.444 yang meliputi biaya ATS/BAHP sebesar Rp 143.797.440,00; biaya perbaikan dan pemeliharaan ringan sebesar $\mathrm{Rp}$ 348.900.008,00; biaya daya dan jasa sebesar Rp 155.929.996,00; biaya transportasi/ perjalanan dinas sebesar Rp 104.400.000,00; biaya konsumsi sebesar Rp 24.920.000,00; biaya pembinaan peserta didik/ ekstrakurikuler sebesar Rp 133.570.000,00; biaya uji kompetensi sebesar $\mathrm{Rp}$ 80.190.000,00; biaya praktek kerja industri sebesar Rp 48.270.000,00; biaya pelaporan sebesar Rp 35.405.000,00; dan biaya lainlain sebesar Rp 138.849.000,00.

Total Bantuan Beasiswa di SMK Negeri 1 Jogonalan Tahun Ajaran 2014/2015 sebesar Rp 287.300.000,00 yang meliputi Beasiswa BSM sebesar Rp 
260.000.000,00; BSKM sebesar Rp 15.000.000,00; Beasiswa Supersemar sebesar Rp 5.400.000,00; Beasiswa dari GNOTA sebesar Rp 6.900.000,00.

Total Biaya Investasi Selain Lahan Pendidikan di SMK Negeri 1 Jogonalan Tahun Ajaran 2014/2015 sebesar Rp 876.968.000,00 yang meliputi pengadaan alat sebesar Rp 356.200.000,00; bangunan sebesar Rp 417.200.000,00; dan pengadaan buku sebesar Rp 103.568.000,00.

Biaya Satuan Pendidikan diperoleh dengan menjumlahkan antara Biaya Operasi dan Biaya Investasi Selain Lahan Pendidikan. Biaya Satuan Pendidikan di SMK Negeri 1 Jogonalan sebesar Rp 5.627.272.509,00. Biaya Satuan Pendidikan per Peserta Didik diperoleh dengan membagi Total Biaya Satuan Pendidikan dengan jumlah peserta didik. Penghitungan Biaya Satuan Pendidikan per Peserta Didik dengan membagi antara Rp 5.627.272.509,00 dan 877 sehingga diperoleh sebesar Rp 6.416.502,29.

Sumber pendanaan di SMK Negeri 1 Jogonalan Tahun Ajaran 2014/2015 berasal dari Anggaran Pendapatan dan Belanja Negara (APBN) sebesar Rp 1.326.100.444,00; Anggaran Pendapatan dan Belanja Daerah Provinsi Jawa Tengah (APBD 1) sebesar Rp 8.000.000,00; Anggaran Pendapatan dan Belanja Daerah Kabupaten Klaten (APBD 2) sebesar Rp 2.474.333.996,00; Sumbangan Orang Tua (SOT) sebesar Rp 1.806.538.069,00; dan Sumber Lain (Gerakan Nasional Orang Tua Asuh dan Beasiswa Supersemar) sebesar Rp 12.300.000,00.

Berdasarkan Peraturaan Pemerintah Nomor 69 Tahun 2009 jumlah Standar Biaya Operasi Nonpersonalia Kabupaten Klaten untuk program keahlian Akuntansi,
Penmasaran, Administrasi Perkantoran, serta Teknik Komputer dan Jaringan sebesar Rp 1.323.786.240 sedangkan jumlah Biaya Operasi Nonpersonalia di SMK Negeri 1 Jogonalan Tahun Ajaran 2014/2015 adalah Rp 1.214.231.444,00.

\section{Pembahasan}

Biaya Operasi meliputi Biaya Operasi Personalia, Biaya Operasi Nonpersonalia, dan Bantuan Beasiswa. Biaya Operasi Personalia adalah biaya yang rutin dikeluarkan sekolah yang berkaitan dengan kesejahteraan personalia Biaya Operasi Nonpersonalia adalah biaya yang rutin dikeluarkan sekolah selain untuk kesejahteraan personalia sekolah. Bantuan beasiswa bertujuan untuk meringankan beban biaya pendidikan peserta didik. Sesuai dengan panduan penghitungan biaya satuan operasional,bantuan beasiswa dapat ditambahkan ke dalam penghitungan Biaya Operasi Satuan Pendidikan jika Pemerintah Kabupaten/Kota mempunyai kebijakan dimana sekolah diminta bertanggung- jawab untuk mengelola dana atas beberapa tambahan selain biaya dan untuk memudahkan administrasi.

$\begin{array}{cccc} & \text { Penghitungan } & \text { Biaya } & \text { Operasi } \\ \text { dengan } & \text { menjumlahkan } & \text { Biaya } & \text { Operasi }\end{array}$ Personalia, Biaya Operasi Nonpersonalia dan Bantuan Beasiswa. Biaya Operasi di SMK Negeri 1 Jogonalan sebesar Rp 4.750.304.509,00. Biaya Operasi Per Peserta Didik diperoleh dengan membagi total Biaya Operasi dengan 877 peserta didik. sehingga diperoleh Rp 5.416.538,78.

Biaya Investasi Selain Lahan Pendidikan yaitu biaya yang dikeluarkan sekolah untuk keperluan pengadaan barang dan jasa selain lahan pendidikan (tanah) yang mempunyai manfaat lebih dari satu 
tahun untuk penyelenggaraan pendidikan. Biaya Investasi Selain Lahan Pendidikan meliputi biaya untuk pengadaan peralatan, bangunan, dan pengadaan buku.

Biaya Investasi Selain Lahan Pendidikan SMK Negeri 1 Jogonalan Tahun Ajaran 2014/2015 sebesar Rp 876.968.000,00 dan Biaya Investasi Selain Lahan Pendidikan Per Peserta Didik diperoleh dengan membagi total Biaya Investasi Selain Lahan Pendidikan dengan 877 peserta didik sehingga diperoleh sebesar Rp 999.963,51.

Biaya Satuan Pendidikan terdiri dari Biaya Operasi dan Biaya Investasi. Di SMK Negeri 1 Jogonalan pada Tahun Ajaran 2014/2015 tidak ada pembelian tanah/lahan sehingga Biaya Satuan Pendidikan diperoleh dengan menjumlahkan antara Biaya Operasi dan Biaya Investasi Selain Lahan Pendidikan. Dari hasil penghitungan diperoleh Biaya Satuan Pendidikan sebesar Rp 5.627.272.509,00 dan Biaya Satuan Pendidikan per Pesera didik Rp 6.416.502,29. Apabila di sekolah terdapat investasi berupa lahan pendidikan maka Biaya Investasi akan naik dan berimplikasi pada kenaikan Biaya Satuan Pendidikan.

Sumber dana di SMK Negeri 1 Jogonalan Tahun Ajaran 2014/2015 berasal dari APBN (Anggaran Pendapatan dan Belanja Negara) sebesar 23,6\%; Anggaran Pendapatan dan Belanja Daerah Provinsi Jawa Tengah (APBD 1) sebesar 0,1\%; Anggaran Pendapatan dan Belanja Daerah Kabupaten Klaten (APBD 2) 44\%; Sumbangan Orang Tua (SOT) sebesar 32,1\%; dan Sumber Lain (Gerakan Nasional Orang Tua Asuh dan Beasiswa Supersemar) sebesar $0,2 \%$.
Dana dari APBN sebesar Rp 1.326.100.444,00 digunakan untuk membiayai Biaya Operasi Personalia Rp 86.070.000,00; Biaya Operasi Nonpersonalia Rp 758.462.444,00; Bantuan Siswa Miskin (BSM) Rp 260.000.000,00; Biaya Investasi Selain Lahan Pendidikan Rp 221.568.000,00. Dana dari APBD 1 (Jawa Tengah) sebesar Rp 8.000.000,00 digunakan untuk Beasiswa Kurang Mampu (BSKM).

Dana dari APBD 2 sebesar Rp 2.474.333.996,00 digunakan untuk membiayai Biaya Operasi Personalia Rp 2.451.739.000,00; Biaya Operasi Nonpersonalia sebesar Rp 15.594.996,00; dan Beasiswa Kurang Mampu (BSKM) Rp 7.000.000,00. Dana dari SOT sebesar Rp 1.806.538.069,00 digunakan untuk membiayai Biaya Operasi Personalia sebesar Rp 710.964.065,00; Biaya Operasi Nonpersonalia Rp 440.174.004,00; Biaya Investasi Selain Lahan Pendidikan Rp 655.400.000,00. Dana dari Sumber Lain sebesar Rp 12.300.000,00 yang berasal dari Beasiswa Supersemar Rp 5.400.000,00; dan GNOTA Rp 6.900.000,00.

$$
\text { Jumlah Biaya Operasi }
$$

Nonpersonalia untuk program keahlian Akuntansi, Pemasaran, Administrasi Perkantoran, serta Teknik Komputer dan Jaringan berdasarkan Peraturan Pemerintah Nomor 69 Tahun 2009 untuk Kabupaten Klaten sebesar $\mathrm{Rp} \quad 1.323 .786 .240,00$ sedangkan di SMK Negeri 1 Jogonalan sebesar Rp 1.214.231.444,00. Terdapat selisih sebesar Rp 109.554.796,00 dibawah peraturan sehingga Biaya Operasi Nonpersonalia di SMK Negeri 1 Jogonalan belum sesuai dengan Peraturan Pemerintah Nomor 69 Tahun 2009. Selisih ini diharapkan SMK Negeri 1 Jogonalan pada tahun ajaran berikutnya untuk menambah 
alokasi dana pada komponen Biaya Operasi Nonpersonalia.

\section{SIMPULAN DAN SARAN}

\section{Simpulan}

Berdasarkan hasil penelitian dan pembahasan pada bab sebelumnya, maka dapat diambil kesimpulan bahwa (1) Biaya Operasi per peserta didik sebesar Rp 5.416.538,78; (2) Biaya Investasi Selain Lahan Pendidikan per peserta didik sebesar Rp 999.963,51; (3) Biaya Satuan Pendidikan per peserta didik sebesar $\mathrm{Rp} 6.416 .502,29$; (4) Sumber dana berasal dari APBN sebesar Rp 1.326.100.444,00; APBD 1 Rp 8.000.000,00; APBD 2 sebesar Rp 2.474.333.996,00; SOT sebesar Rp 1.806.538.069,00; dan Sumber lain sebesar Rp 12.300.000,00. (5) Biaya Operasi Nonpersonalia di SMK Negeri 1 Jogonalan belum sesuai dengan Standar Biaya Operasi Nonpersonalia di Kabupaten Klaten. Jumlah Biaya Operasi Nonpersonalia di Kabupaten Klaten sebesar Rp 1.323.786.240,00 sedangkan di SMK Negeri 1 Jogonalan sebesar Rp 1.214.231.444,00.

\section{Saran}

Berdasarkan pada hasil penelitian ini, peneliti memberikan saran kepada beberapa pihak sebagai berikut:

\section{Bagi Pemerintah}

a. Hasil penelitian dapat digunakan sebagai pertimbangan pemerintah dalam menetapkan alokasi bantuan pendanaan untuk sekolah.

b. Pemerintah pusat maupun daerah dapat menyelenggarakan diklat/workshop mengenai penyusunan anggaran Biaya Satuan Pendidikan untuk Sekolah Menengah Kejuruan pada pengelola keuangan sekolah agar sesuai standar pemerintah.

c. Pemerintah Provinsi Jawa Tengah sebaiknya meninjau alokasi bantuan karena bantuan pendanaan yang diberikan hanya Rp 8.000.000,00 dalam setahun.

\section{Bagi SMK Negeri 1 Jogonalan}

a. Hasil penelitian ini dapat dijadikan sebagai bahan kajian dalam penghitungan biaya satuan pendidikan.

b. Pengalokasian dana untuk Biaya Operasi Nonpersonalia sebaiknya mengacu pada Peraturan Pemerintah Nomor 69 Tahun 2009 karena anggaran di SMK Negeri 1 Jogonalan masih dibawah standar Kabupaten Klaten.

c. Penambahan alokasi dana untuk biaya alat tulis/bahan dan alat habis pakai karena hanya $12 \%$ dari total Biaya Operasi Nonpersonalia sedangkan menurut Peraturan Pemerintah Nomor 69 Tahun 2009 alokasi untuk alat tulis 10\% dan bahan alat habis pakai $10 \%$ untuk Akuntansi, Administrasi Perkantoran, Pemasaran serta 12\% untuk Teknik Komputer dan Jaringan.

d. Sekolah sebaiknya membuat dokumen anggaran biaya untuk masing-masing program keahlian agar dapat mengetahui kebutuhan biaya operasi dan investasi karena masing-masing program keahlian membutuhkan keperluan kebutuhan yang berbeda.

\section{Masyarakat/Orang Tua}

Hasil penelitian ini dapat dijadikan informasi mengenai jumlah biaya yang dibutuhkan dalam pendidikan di sekolah dan besarnya dana tambahan yang masih dibutuhkan untuk menutup biaya sehingga 
sekolah masih mengadakan pungutan kepada orang tua.

\section{DAFTAR PUSTAKA}

Harsono. (2007). Pengelolaan Pembiayaan Pendidikan. Yogyakarta: Pustaka Book Publisher

Nanang Fattah. (2002). Ekonomi dan pembiayaan pendidikan. Bandung: PT Remaja Rosdakarya

Peraturan Pemerintah Nomor 19 Tahun 2005 tentang Standar Nasional Pendidikan

Peraturan Pemerintah Nomor 48 Tahun 2008 tentang Pendanaan Pendidikan

Peraturan Pemerintah Nomor 65 Tahun 2005 tentang Pedoman Penyusunan dan Penerapan Standar Pelayanan Minimal 